\title{
Mucosal argyrophil endocrine cells in pernicious anaemia and upper gastrointestinal carcinoid tumours
}

\author{
S-M SJÖBLOM,* P SIPPONEN, $\dagger$ S-L KARONEN, $\ddagger$ HJ JÄRVINEN \\ From the ${ }^{*}$ Second Department of Surgery and the $\ddagger$ Department of Clinical Chemistry, Helsinki University \\ Central Hospital, and the †Department of Pathology, Jorvi Hospital, Espoo, Finland
}

SUMMARY The number and density of argyrophil endocrine cells were morphometrically calculated in gastric fundal mucosal biopsy specimens taken from 64 patients with pernicious anaemia (five with gastric carcinoids, 15 with nodular argyrophil cell hyperplasia, 44 with diffuse argyrophil cell hyperplasia) and from 14 healthy controls. Similar calculations were also made on the ileal mucosa away from the tumour of 10 patients with ileal carcinoids and 10 controls. In the stomach, the argyrophil cell counts were twice as high in the patients with pernicious anaemia than in controls and the densities in the whole mucosa or in the epithelial structures were similarly three to five times higher. The cell counts in the patients showed positive correlation with the serum gastrin concentration. The patients with nodular argyrophil cell hyperplasia and gastric carcinoids formed a uniform group with the highest cell counts and serum gastrin concentrations; the difference between the groups was in the longer duration of pernicious anaemia in the patients with carcinoid tumours. On the other hand, no endocrine cell hyperplasia was seen in those with ileal carcinoids.

It is concluded that fundal mucosal endocrine cells show an increase in patients with pernicious anaemia that is related to the gastrin concentration. This phenomenon may favour the development of hyperplastic endocrine cell nodules and, eventually, carcinoid tumours.

Mucosal endocrine cells and endocrine tumours (carcinoids) occur throughout the gastrointestinal tract. ${ }^{1-3}$ Unlike appendiceal, colonic, and rectal carcinoids, these tumours in the stomach are multifocal in $13-36 \%$ and in the small bowel in $29-41 \%^{78}$ of cases respectively. This multifocality might indicate a role for hormonal factors in the pathogenesis and growth of these tumours; recent studies have shown the presence of hormonal trophic mechanisms in the control of gastric fundic mucosal endocrine cells by gastrin. ${ }^{9}$

That gastrin might have trophic influence on fundal endocrine cells is based on finding an increased density of these cells in conditions with hypergastrinaemia such as Zollinger-Ellison syndrome, ${ }^{10}$ type $\mathrm{A}$ atrophic gastritis with or without pernicious anaemia, "and in experimental animals with achlorhydria caused by potent acid secretion inhibitors. ${ }^{12}$ Hypergastrinaemia is also a predisposing factor for gastric carcinoids ${ }^{13-15}$ which are relatively common in pernicious anaemia. 1617

An aetiological role for gastrin in the pathogenesis of fundic carcinoids in pernicious anaemia could be

Accepted for publication 6 October 1988 expected to correlate directly with the degree of hormonal stimulus and the number of endocrine cells. In this morphometric study we investigated: (i) whether the argyrophil endocrine cells in the fundal mucosa of patients with pernicious anaemia represented a distinct hyperplasia-that is, whether there were increased counts of endocrine cells in pernicious anaemia; and (ii) whether the patients with pernicious anaemia and gastric carcinoid tumours were those with the most extreme hypergastrinaemia and hyperplasia of fundic endocrine cells. To test the hypothesis of hormonal control of ileal endocrine cells and ileal carcinoids, we performed corresponding morphometric analysis of argyrophil and argentaffin endocrine cells in the ileal mucosa of 10 patients with ileal carcinoids and in 10 control patients.

\section{Patients and methods}

STUDY OF GASTRIC ENDOCRINE CELLS

Sixty four patients with pernicious anaemia treated at the Meilahti Clinics of Helsinki University Central Hospital between 1972 and 1985 and 14 randomly selected healthy controls were studied. The mean age of the patients ( 39 women and 25 men) was 59 years, range $24-75$ years. 


\section{STUDY OF ILEAL ENDOCRINE CELLS}

Ten patients with ileal carcinoid tumours surgically treated at the Meilahti Clinics of Helsinki University Central Hospital between 1978 and 1987, and 10 control patients who had right-sided hemicolectomy or ileal resection for other reasons at Jorvi Hospital between 1985 and 1987, were studied. The mean age of the patients with carcinoid tumours (three women and seven men) was 54 years, range 42-74 years.

Mucosal specimens obtained at gastroscopy consisted of numerous random antral and fundal specimens and biopsy specimens from any polypoid lesions or discoloured areas.

The ileal specimens were obtained at laparotomy. The ileal carcinoids were solitary in six cases and occurred at multiple sites in four. They were located 40 to $300 \mathrm{~cm}$ (most of them $50-100 \mathrm{~cm}$ ) proximal to the ileocaecal valve. In six cases there were separate specimens of normal and neoplastic bowel, and in four cases the tumour was in the same block as nonneoplastic bowel. The control patients had a right colectomy for carcinoma in the caecum or in the ascending colon, except for one patient who had an ileal resection because of a Meckel's diverticulum. The control specimens therefore composed nine cases from the terminal ileum $(15-20 \mathrm{~cm}$ proximal to the ileocaecal valve) and one sample from more proximal ileum.

The specimens were fixed overnight in neutral buffered $10 \%$ formalin and embedded in paraffin wax. Sections $(4 \mu \mathrm{m})$ were stained with haematoxylin and eosin, alcian blue ( $\mathrm{pH} 2.5$ ) and periodic acid Schiff, and Grimelius, and for the ileal specimens, MassonFontana methods. It was anticipated that Grimelius staining would show most of the endocrine cells. ${ }^{18}$

The gastroscopic screening had shown type A chronic atrophic gastritis (severe atrophy of the fundal region with a spared antrum) in all patients with pernicious anaemia but one. This single patient also had severe atrophy of the antral mucosa. Five patients had gastric carcinoid tumours which consisted of small round uniform cells arranged in nests and Grimelius staining showed dark cytoplasmic granularity in most tumour cells (fig 1). These five patients and 15 further patients, had nodular hyperplasia of endocrine cells (fig 2), defined as clusters of five or more argyrophil cells in the fundal region. ${ }^{16}$ These clusters or nodules of argyrophil cells were located in the lower part of the fundal mucosa, or formed separate islands in the muscularis mucosae. The carcinoid tumours differed from the hyperplastic nodules because of their infiltrative growth pattern; they extended in the mucosa to at least the level of the muscularis mucosae. The patients with pernicious anaemia have been characterised and the screening results published earlier. ${ }^{17}$ Both antral and fundal mucosal biopsy specimens of the controls were histologically normal.

The ileal carcinoids were histologically typical and composed of round nests or cords of relatively uniform cells with few mitoses. In all tumours most cells were strongly argyrophilic with dark cytoplasmic granularity on Grimelius staining. Five carcinoids were also strongly argentaffinic, with positive MassonFontana staining in most tumour cells, but five additional tumours had weaker argentaffinity and showed scattered positive cells.

\section{MOR PHOMETR Y}

A square plate with regularly dispersed points (64 points) was used to calculate the counts and densities of the argyrophil endocrine cells in tissue sections (fig 3). The height of the ileal crypts and the length of the villi were measured with the ocular micrometer and magnification of $\times 400$, and the number of villi within a standard length of the ileal mucosa was counted at a magnification of $\times 40$.

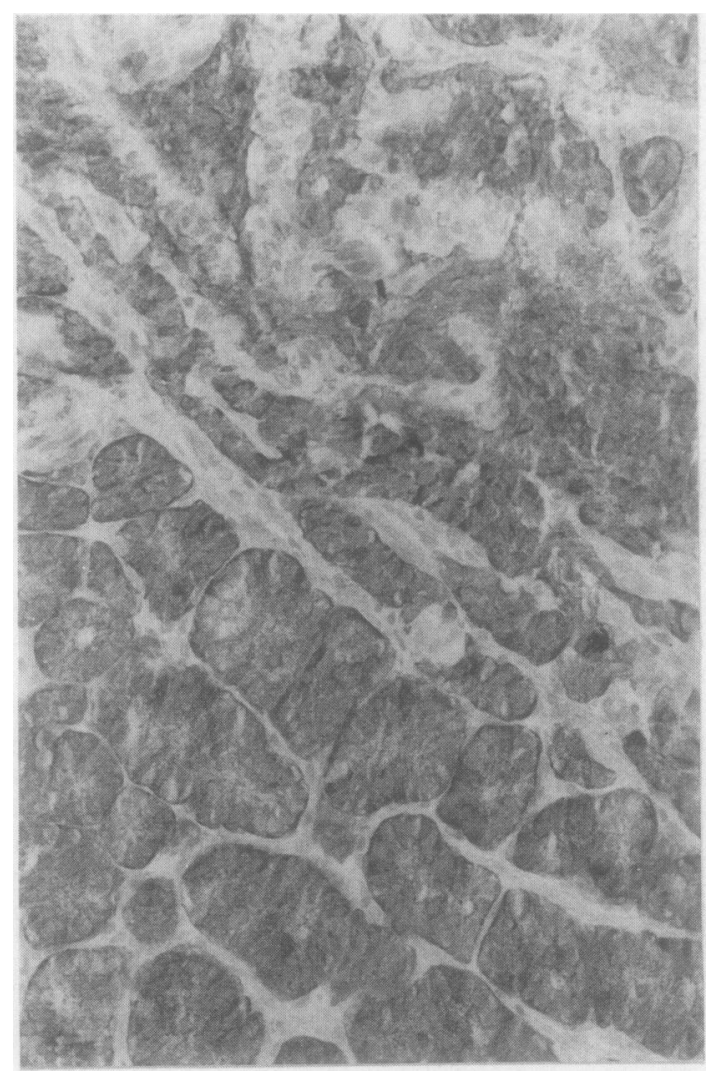

Fig 1 Gastric carcinoid tumour showing trabecular growth pattern and dark cytoplasmic granularity with Grimelius staining. 


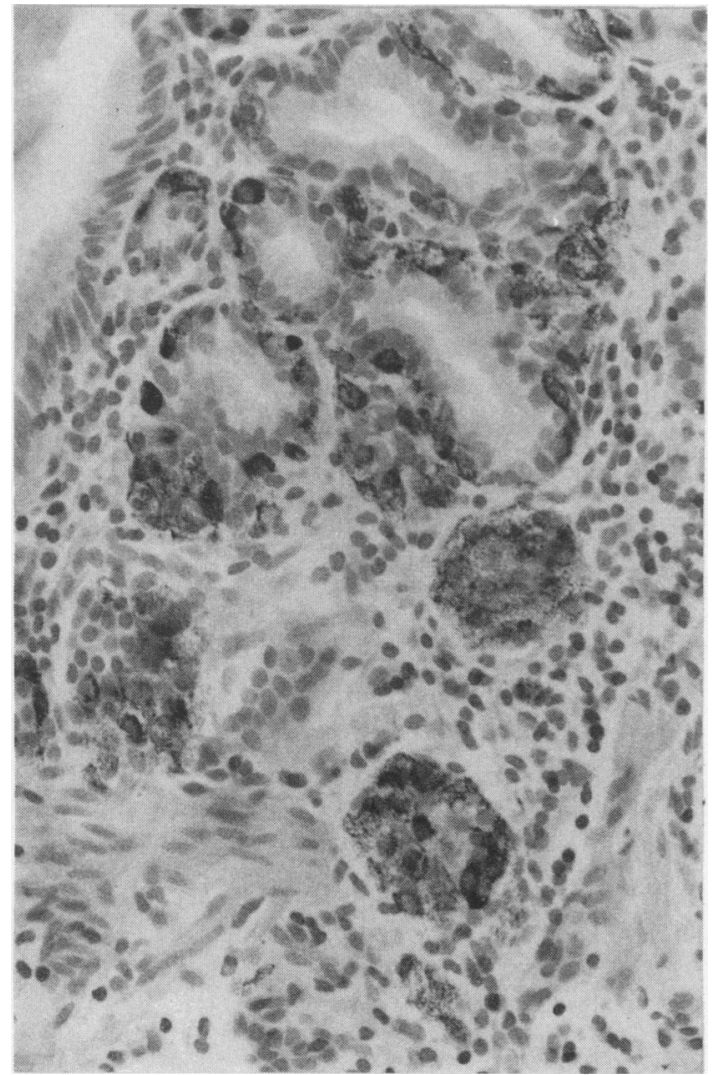

Fig 2 Nodular argyrophil cell hyperplasia presenting as clusters of these cells in lower part of the fundal mucosa. (Grimelius staining.)

Calculations on the gastric specimens were made in three separate areas of sections in from one to four fundal mucosal biopsy specimens, amounting to between three and 12 areas (mean (SD) $6.2(2.5)$ ) for each patient. For the ileal samples, five separate areas were calculated per patient. Only sections in which the whole mucosa from the muscularis mucosae to the surface epithelium (or the top of ileal villi) could be seen were accepted for the measurements. The data presented are the mean values for each patient.

Fasting serum gastrin was measured by a GASKPR radioimmunoassay kit from Oris company, France (normal range 5-50 pmol/1). According to the information provided the antiserum used in the assay stained "big-gastrin".

The significance of differences in various groups was estimated with Wilcoxon's rank sum test. This nonparametric test was used because of slight deviations from normal distribution, differences in variances, and small numbers of patients in some groups. The correlations between serum gastrin concentrations and numbers of argyrophil cells were estimated with the Spearman rank correlation test.

\section{Results}

VOLUME OF MUCOSA AND EPITHELIAL STRUCTURES

In fundal mucosa the ratio between the mucosal volume of the patients with pernicious anaemia (mean (SD) 122 points (15)) and that of the controls (176(26) points) was $1: 1 \cdot 4$; the corresponding ratio between the volumes of the epithelial structures was $1: 2 \cdot 1$.

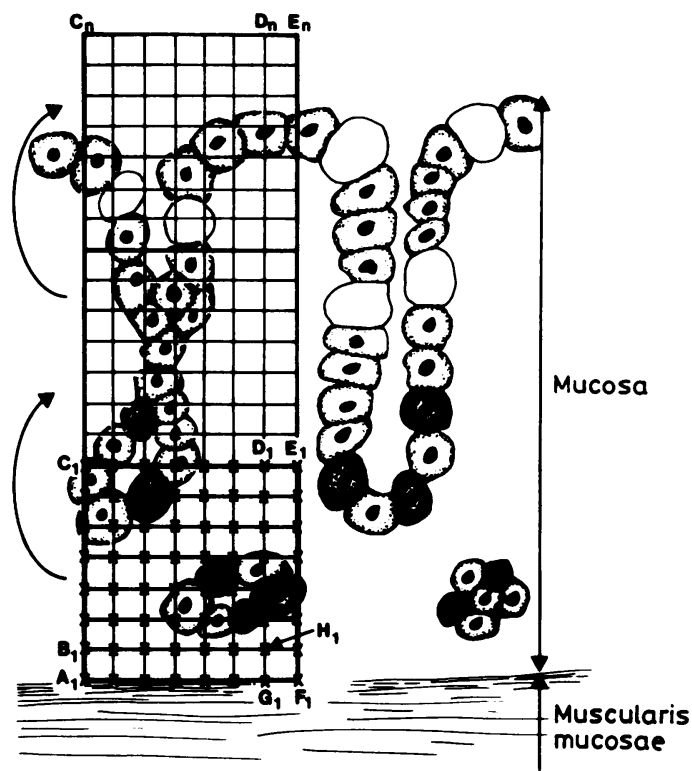

Standard length unit of the mucosa: distance A-F Volume of the mucosa: count of points in rectangle $B_{1} C_{n} D_{n} H_{1}$ that correspond to the mucosal structures above the muscularis mucosae layer

Volume of the epithelial elements: count of points in rectangle $B_{1} C_{n} D_{n} H_{1}$ that correspond to the epithelial cells and glands

Count of neuroendocrine cells: count (number) of neuroendocrine cells within the rectangle $A, C_{n} E_{2} F_{1}$ including the cells that are attached to the lines $A C$ and $C E$ but excluding the cells that are attached to the lines EF and AF.

The following arbitrary indicators were calculated: Number (count) of neuroendocrine cells: count of neuroendocrine cells/standard length unit of the mucosa; Density of neuroendocrine cells in mucosa: count of neuroendocrine cells/volume of the mucosa;

Density of neuroendocrine cells in epithelial elements: count of neuroendocrine cells/volume of glandular-epithelial structures.

Fig 3 Schematic presentation of morphometric detail of endocrine cells. Ocular raster plate is placed on tissue section above muscularis mucosae layer and moved stepwise towards surface epithelium until calculations are completed in the whole thickness of the mucosa. 

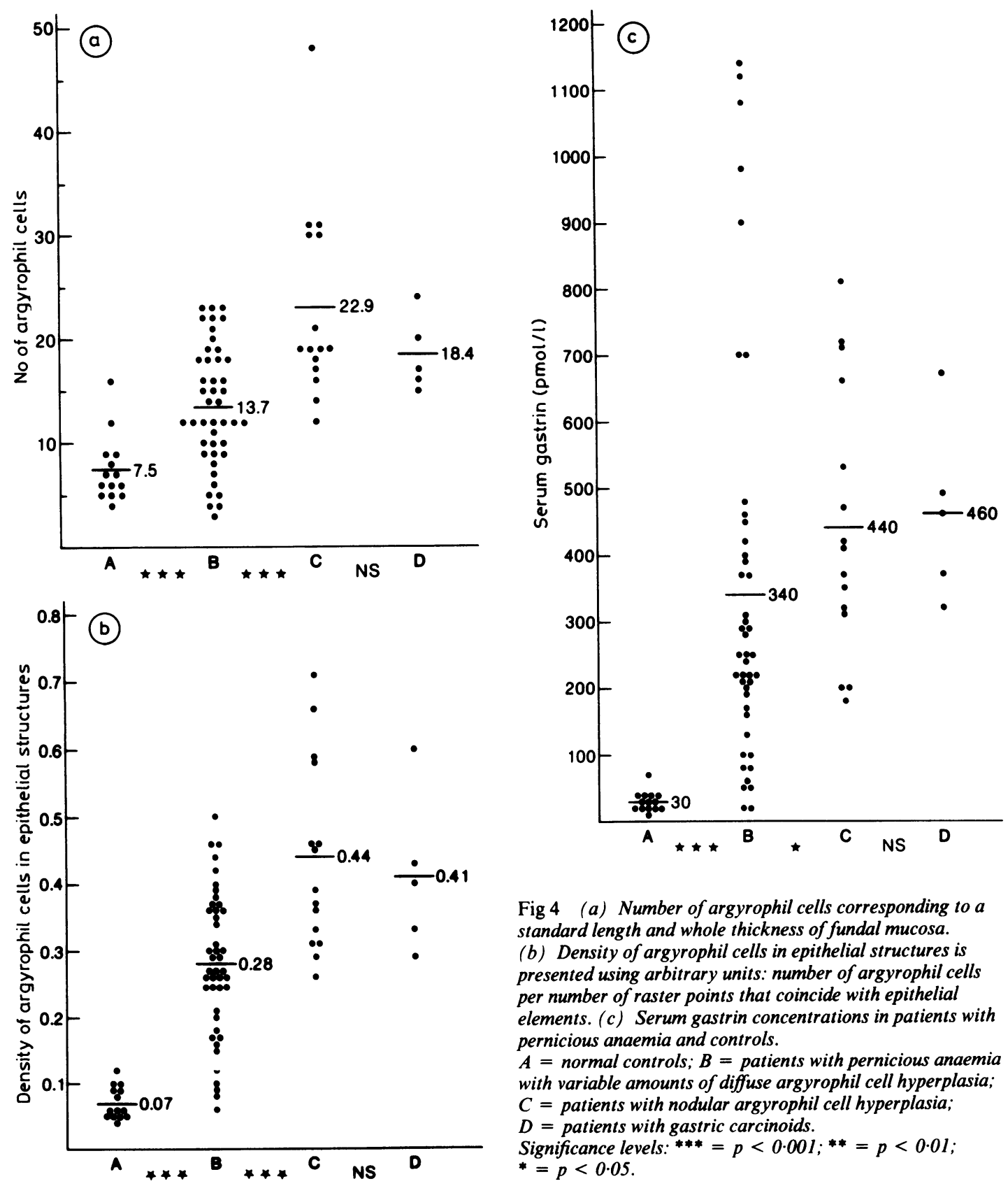

Fig 4 (a) Number of argyrophil cells corresponding to a standard length and whole thickness of fundal mucosa. (b) Density of argyrophil cells in epithelial structures is presented using arbitrary units: number of argyrophil cells per number of raster points that coincide with epithelial elements. (c) Serum gastrin concentrations in patients with pernicious anaemia and controls.

$A=$ normal controls; $B=$ patients with pernicious anaemia with variable amounts of diffuse argyrophil cell hyperplasia; $C=$ patients with nodular argyrophil cell hyperplasia; $D=$ patients with gastric carcinoids.

Significance levels: ${ }^{* * *}=p<0.001 ;{ }^{* *}=p<0.01$; $*=p<0.05$.

These ratios confirmed that atrophy and flattening of the mucosa were present, and that there was severe loss of the epithelial and glandular structures in the fundal region of the patients with pernicious anaemia compared with the controls.

In ileal mucosa the ratios between the volumes of

the mucosa, the numbers of the villi, the heights of the villi and the depths of the crypts in the patients with and without ileal carcinoids were $1: 1 \cdot 1,1: 1,1: 1 \cdot 2$, and $1: 1 \cdot 2$, respectively. This suggested that there was relative uniformity of the mucosal structures in the patients with carcinoid tumours and the controls. 


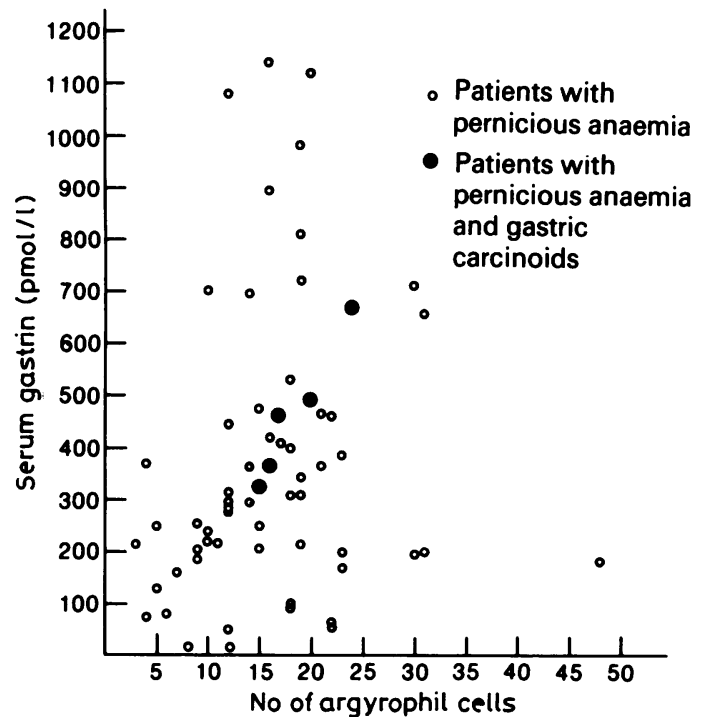

Fig 5 Relation of serum gastrin concentration and argyrophil cell count in patients with pernicious anaemia.

\section{GASTRIC ARGYROPHIL CELLS}

Most of the argyrophil cells were in the lower part of the fundal mucosa both in the patients and controls: only a few scattered cells occurred in the surface epithelium.

The mean number of argyrophil cells in the standard length of the mucosa was significantly higher $(\mathrm{p}<0.001)$ in patients with pernicious anaemia (mean 16.0, range 3-48) than in normal controls (mean $7 \cdot 5$, range 4-16). Patients with pernicious anaemia with simple fundal atrophic gastritis had a slight increase of the mean count of argyrophil cells ( 1.8 times above the normal controls) and those with nodular hyperplasia of argyrophil cells and those with frank gastric carcinoids had a pronounced increase of argyrophil cells $(3 \cdot 1-2 \cdot 5$ times above the normal controls) (fig 4a). The difference between these groups was highly significant $(p<0.001)$.

The differences between the groups of the patients with pernicious anaemia and the normal controls were even greater when the densities of argyrophil cells were considered in a given volume of mucosa or a given volume of epithelium. The mean densities in patients with simple atrophic gastritis, nodular argyrophil cell hyperplasia, and gastric carcinoids were $2 \cdot 8-4 \cdot 0,4 \cdot 5-$ 6.3 , and 3.8-5.9 times higher, respectively, than in normal controls (fig 4b).

\section{SERUM GASTRIN AND ARGYROPHIL CELL}

HY PER PLASIA

The highest concentrations of serum gastrin were observed in the patients with pernicious anaemia and gastric carcinoid tumours (mean (SD) 464 (118) pmol/
Table Correlation between serum gastrin concentration and argyrophil endocrine cell counts in fundal mucosal biopsy specimens of patients with pernicious anaemia

\begin{tabular}{|c|c|c|}
\hline & $\begin{array}{l}\text { All patients with } \\
\text { pernicious anaemia }\end{array}$ & $\begin{array}{l}\text { Patients without } \\
\text { nodular hyperplasia or } \\
\text { carcinoid tumours }\end{array}$ \\
\hline $\begin{array}{l}\text { Duration of } \\
\text { pernicious anaemia } \\
\text { (years) }\end{array}$ & $\begin{array}{l}\text { Correlation } \\
\text { coefficient } \\
(\boldsymbol{r})\end{array}$ & $\begin{array}{l}\text { Correlation } \\
\text { coefficient } \\
(r)\end{array}$ \\
\hline $1-5$ & \multirow{4}{*}{$\begin{array}{c}-0.084 \\
(p=0.625)(n=36) \\
0.580 \\
(p=0.019)(n=17) \\
0.676 \\
(p=0.031)(n=11) \\
0.264 \\
(p=0.034)(n=64)\end{array}$} & \multirow{4}{*}{$\begin{array}{l}-0.120 \mathrm{p}=0.541 \\
(\mathrm{n}=28) \\
0.508 \mathrm{p}=0.124 \\
(\mathrm{n}=10) \\
0.486 \mathrm{p}=0.277 \\
(\mathrm{n}=6) \\
0.224 \mathrm{p}=0.138 \\
(\mathrm{n}=44)\end{array}$} \\
\hline $6-10$ & & \\
\hline $11-$ & & \\
\hline Total & & \\
\hline
\end{tabular}

1) and those with nodular argyrophil cell hyperplasia (443 (195) pmol/l), compared with the patients with pernicious anaemia but without carcinoids and nodular argyrophil cell hyperplasia (mean (SD) 343 (295) pmol/l), or the controls (30 (14) pmol/l) (fig 4c). The groups of patients with gastric carcinoids and nodular hyperplasia of argyrophil cells were almost identical. The gastric carcinoid tumours were clearly associated with raised serum gastrin concentrations, but not with the highest concentrations seen in pernicious anaemia.

In the patients with pernicious anaemia serum gastrin concentrations and the number of argyrophil cells showed a positive linear correlation $(r=0.264$, $p=0.034$ ) (fig 5). The correlation was independent of age but dependent on the duration of pernicious anaemia (table): it gradually improved with increasing duration of pernicious anaemia, and was significant only if patients with pernicious anaemia and carcinoid tumours and nodular hyperplasia of argyrophil cells were included in the calculations. The correlation was best in the patients with carcinoid tumours $(r=1 \cdot 0$, $\mathrm{p}=0.043, \mathrm{n}=5$ ).

\section{DURATION OF PERNICIOUS ANAEMIA}

The patients with pernicious anaemia and gastric carcinoids were characterised by an early onset and long duration of pernicious anaemia. The time interval from the diagnosis of pernicious anaemia to the present examination in the carcinoid group was between six and 18 years (mean 12 years), in the group with nodular argyrophil cell hyperplasia between one and 15 years (mean six years), and in the other patients between one and 14 years (mean five years).

\section{ILEAL ARGYROPHIL AND ARGENTAFFIN CELLS}

There were no differences in site, distribution, or clustering of argyrophil or argentaffin cells in the ileal mucosa of the patients with or without ileal carcinoids. 
Furthermore, no clear differences were found in counts of argyrophil or argentaffin endocrine cells (figs $6 a$ and $b)$.

\section{Discussion}

Our calculations show proliferation of argyrophil endocrine cells in the fundal mucosa of patients with pernicious anaemia, and are in accordance with the several earlier qualitative ${ }^{1119-21}$ and the few published quantitative studies. ${ }^{916}$ In a given volume of mucosa or epithelium the densities of argyrophil endocrine cells were three to four times higher in the patients with pernicious anaemia than in the controls. Pernicious anaemia, however, is accompanied by a great reduction (in the present study $30-50 \%$ ) in the fundal mucosal volume and in the volume of epithelial structures. If corrected and adjusted for these reductions, the calculations indicated that there was about a twofold increase in the absolute number of argyrophil cells in the patients with pernicious anaemia in general, and about a threefold increase in those with gastric carcinoids and nodular argyrophil cell hyperplasia, compared with normal fundal mucosa. The data indicate a true hyperplasia of argyrophil cells in the fundal mucosa in pernicious anaemia, rather than a possibly false image created by an increased argyrophil cell density due to the loss of non-endocrine epithelial cells.

In rat stomachs the number of fundal endocrine cells has been shown to be linearly related to serum gastrin concentrations when acid secretion is totally or subtotally inhibited, or when the physiology of the stomach is manipulated by various surgical procedures. ${ }^{22} 23$ In man a corresponding relation has been shown in patients with pernicious anaemia by Borch et al. ${ }^{9}$ Our observations can be considered in the light of these studies. The correlation between fundal
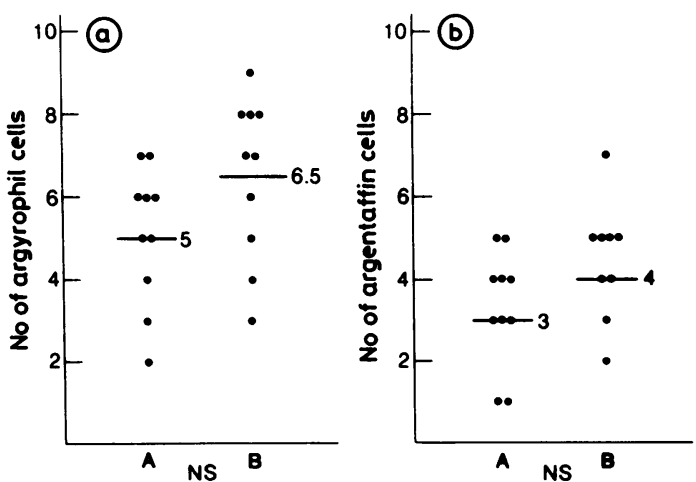

Fig 6 Number of argyrophil (a) and argentaffin (b) cells corresponding to standard length of ileal mucosa. $A=$ control patients; $B=$ patients with ileal carcinoids. endocrine cell counts and serum gastrin concentrations was positive even though relatively weak in the patients with pernicious anaemia in general; it improved with increasing duration of pernicious anaemia and was significant only if the patients with pernicious anaemia and gastric carcinoids and nodular argyrophil cell hyperplasia were included in the calculations. Remarkable discrepancies were found between endocrine cell counts and serum gastrin concentrations: the highest serum gastrin concentrations did not correlate well with the highest cell counts and, furthermore, the patients with pernicious anaemia and carcinoid tumours or nodular argyrophil cell hyperplasia showed high but not the highest serum gastrin concentrations. Failures in morphometry or errors in biopsy sampling may explain some of these discrepancies. On the other hand, gastrin consists of several molecular forms with different lengths of amino acid chain. ${ }^{24}$ Whether these various forms of gastrin also differ in respect of their trophic effects on fundal endocrine cells remains to be investigated.

Long term hypergastrinaemia has been shown to induce gastric carcinoid tumours in the fundal mucosa of rats. ${ }^{1525}$ There is also an increasing list of reports of patients with pernicious anaemia and gastric carcinoids that, typically, are multifocal, small, and usually subclinical. ${ }^{141626}$ In our series of 64 patients with pernicious anaemia, gastric carcinoid tumours were found on endoscopy and biopsy in five cases, and 15 additional patients showed "nodular hyperplasia" of endocrine cells, defined as the presence of clusters containing five or more adjacent argyrophil endocrine cells. Solcia et $a l^{27}$ and Müller et al ${ }^{28}$ suggested that these nodular hyperplastic clusters might represent precursor lesions of carcinoid tumours. Our present data support this view. With regard to mean serum gastrin concentrations and argyrophil cell counts, we could not find any significant differences between the carcinoid patients and those with nodular argyrophil cell hyperplasia, whereas these groups differed significantly from the patients with pernicious anaemia who did not have endoscopically apparent tumours or histologically confirmed hyperplastic nodules. On the other hand, the mean duration of pernicious anaemia was shorter (mean six years) in the patients with nodular argyrophil cell hyperplasia than in those with carcinoids (mean 12 years), indicating the presence of gradual time-related sequences in these processes.

Our observations therefore indicate a correlation between serum gastrin concentrations, counts of argyrophil cells, duration of pernicious anaemia and the development of gastric carcinoid tumourssuggesting that the pathogenesis of gastric carcinoids in pernicious anaemia might, indeed, be based on the 
hyperplasia of fundal endocrine cells induced by gastrin. Although the small multifocal carcinoid tumours associated with pernicious anaemia are usually clinically silent and show malignant behaviour in only a few cases, ${ }^{41626}$ the importance of the hyperplasia-carcinoid sequence would be in finding the patients with pernicious anaemia with the highest risk of developing gastric carcinoids. The great variations in the serum gastrin values of the patients with pernicious anaemia and the occurrence of gastric carcinoids, even with only moderately increased serum gastrin concentrations, make this laboratory examination impractical for determining the risk of developing gastric carcinoids in any one patient. It might, however, be worth while following up young patients with pernicious anaemia who will have the disease for a long time, especially if their fundal mucosal biopsy specimens show nodular hyperplasia of argyrophil cells, which may be regarded as a precursor for gastric carcinoids.

Ileal carcinoids are similar to gastric carcinoids because of their multifocality. ${ }^{78}$ There are a few conflicting reports about the possible hyperplasia of ileal endocrine cells in association with ileal carcinoid tumours. ${ }^{2930}$ Our calculations did not indicate hyperplasia of either argyrophil or argentaffin endocrine cells in the ileal mucosa of patients with ileal carcinoids. This suggests that carcinoid tumours of the gastrointestinal tract probably vary in their morphogenesis and pathogenesis. The proliferation of endocrine cells and the subsequent risk of carcinoid tumours might therefore be a unique phenomenon of gastric fundal mucosa.

\section{References}

1 Sjölund K, Sanden G, Håkanson R, Sundler F. Endocrine cells in human intestine: an immunocytochemical study. Gastroenterology 1983;85:1120-30.

2 Solcia E, Capella C, Buffa R, et al. The diffuse endocrine-paracrine system of the gut in health and disease: ultrastructural features. Scand J Gastroenterol 1981;16(suppl 70):25-36.

3 Godwin JD. Carcinoid tumors. An analysis of 2837 cases. Cancer 1975;36:560-9.

4 Johansson $\mathrm{H}$, Wilander $\mathrm{E}$. A clinical study of 30 gastric carcinoids. Upsala J Med Sci 1982;87:135-42.

5 Mizuma K, Shibuya H, Totsuka M, Hayasaka H. Carcinoid of the stomach: a case report and review of 100 cases reported in Japan. Ann Chir Gynaecol 1983;72:23-7.

6 Sjöblom S-M, Haapiainen R, Miettinen M, Järvinen H. Gastric carcinoid tumours and atrophic gastritis. Acta Chir Scand 1987;153:37-43.

7 Mårtensson H, Nobin A, Sundler F. Carcinoid tumors in the gastrointestinal tract-an analysis of 156 cases. Acta Chir Scand 1983;149:607-16.

8 Moertel CG, Sauer WG, Dockerty MB, Baggenstoss AH. Life history of the carcinoid tumor of the small intestine. Cancer 1961;14:901-12.

9 Borch K, Renvall H, Liedberg G, Andersen BN. Relations between circulating gastrin and endocrine cell proliferation in the atrophic gastric fundic mucosa. Scand $J$ Gastroenterol 1986;21:357-63.
10 Bordi C, Cocconi G, Togni R, Vezzadini P, Missale G. Gastric endocrine cell proliferation. Association with Zollinger-Ellison syndrome. Archives of Pathology 1974;98:274-8.

11 Rubin W. Proliferation of endocrine-like (enterochromaffin) cells in atrophic gastric mucosa. Gastroenterology 1969;57:641-8.

12 Harleman JH, Betton GR, Dormer G, McCrossan M. Gastric neuroendocrine cell hyperplasia after treatment with the long-acting, potent $\mathrm{H}_{2}$-receptor antagonist SK\&F 93479. Scand J Gastroenterol 1987;22:595-600.

13 Mignon M, Lehy T, Bonnefond A, Ruszniewski P, Labeille D, Bonfils S. Development of gastric argyrophil carcinoid tumors in a case of Zollinger-Ellison syndrome with primary hyperparathyroidism during long-term antisecretory treatment. Cancer 1987;59:1959-62.

14 Borch K, Renvall H, Kullman E, Wilander E. Gastric carcinoid associated with the syndrome of hypergastrinemic atrophic gastritis. A prospective analysis of 11 cases. Am J Surg Pathol 1987;11:435-44.

15 Poynter D, Pick CR, Harcourt RA, et al. Association of long lasting unsurmountable histamine $\mathrm{H}_{2}$ blockade and gastric carcinoid tumours in the rat. Gut 1985;26:1284-95.

16 Borch K, Renvall H, Liedberg G. Gastric endocrine cell hyperplasia and carcinoid tumours in pernicious anaemia. Gastroenterology 1985;88:638-48.

17 Sjöblom S-M, Sipponen P, Miettinen M, Karonen S-L, Järvinen H. Gastroscopic screening for gastric carcinoids and carcinoma in pernicious anaemia. Endoscopy 1988;20:52-6.

18 Grimelius L, Wilander E. Silver stains in the study of endocrine cells of the gut and pancreas. Invest Cell Pathol 1980;3:3-12.

19 Goldman H, French S, Burbige E. Kulchitsky cell hyperplasia and multiple metastasizing carcinoids of the stomach. Cancer 1981;47:2620-6.

20 Carney JA, Go VLW, Fairbanks VF, Moore SB, Alport EC, Nora FE. The syndrome of gastric argyrophil carcinoid tumors and non-antral gastric atrophy. Ann Intern Med 1983;99:761-6.

21 Mendelsohn G, de la Monte S, Dunn JL, Yardley JH. Gastric carcinoid tumors, endocrine cell hyperplasia, and associated intestinal metaplasia. Cancer 1987;60:1022-31.

22 Håkanson R, Böttcher G, Sundler F, Vallgren S. Activation and hyperplasia of gastrin and enterochromaffin-like cells in the stomach. Digestion 1986;35(suppl 1):23-41.

23 Sundler F, Hảkanson $R$, Carlsson E, Larsson $H$, Mattsson $H$. Hypergastrinemia after blockade of acid secretion in the rat: trophic effects. Digestion 1986;35(suppl 1):56-69.

24 Rehfeld JF, Stadil F, Vikelsoe J. Immunoreactive gastrin components in human serum. Gut 1974;15:102-11.

$25 \mathrm{Havu}$ N. Enterochromaffin-like cell carcinoids of gastric mucosa in rats after life-long inhibition of gastric secretion. Digestion 1986;35(suppl 1):42-55.

26 Harvey RF, Bradshaw MJ, Davidson CM, Wilkinson SP, Davies PS. Multifocal gastric carcinoid tumours, achlorhydria, and hypergastrinaemia. Lancet 1985;1:951-4.

27 Solcia E, Capella C, Sessa F, et al. Gastric carcinoids and related endocrine growths. Digestion 1986;35(suppl 1):3-22.

28 Müller J, Kirchner T, Müller-Hermelink HK. Gastric endocrine cell hyperplasia and carcinoid tumours in atrophic gastritis type A. Am J Surg Pathol 1987;11:909-17.

29 Hedinger C, Hardmeier T, Funk HU. Das argentaffine System des Verdauungstraktes bei Carcinoidsyndrom. Virchows Arch Pathol Anat 1966;340:304-11.

30 Sherman SP, Li C-Y, Carney JA. Microproliferation of enterochromaffin cells and the origin of carcinoid tumors of the ileum. Arch Pathol Lab Med 1979;103:639-41.

Requests for reprints to: Dr S M Sjöblom, Second Department of Surgery, Helsinki University Central Hospital, Haartmaninkatu 4, SF-00290 Helsinki, Finland. 